and a new linkage in the mouse, and a third is devoted to the colour inheritance and sex-determination in the fish, Lebistes. From the plant side come two papers : one on the interaction of self-incompatibility genes when, contrary to their usual situation, two are present in the same pollen grain; and one on the theory of breeding plants for increased yield. Two further papers consider the effects of natural selection, in one as exemplified by change with time in frequency of certain chromosome types in Drosophila, and in the other by the change with climate in frequency of a gene causing a waxy bloom in Ricinus. Finally, there is a statistical discussion of the measurement and analysis of virulence in bacteria and viruses, as it might be applied to genetical work.

\section{International Union of Biological Sciences}

THIS Union held its first post-war meeting at Copenhagen at the end of July. It was attended by delegates from the various sections and from seventeen countries. Dr. Joseph Needham attended the meeting on behalf of the United Nations Educational, Scientific and Cultural Organisation, and Prof. Borel and M. Establier on behalf of the International Council of Scientific Unions. It was agreed to form new sections of experimental cytology, embryology, genetics, microbiology and zoology. In addition to the Joint Commission on Oceanography on which the Union is represented, it was agreed to form certain new committees on border-line subjects and to invite other unions to nominate members: the subjects agreed upon were radiobiology and natural calamities. A long list of congresses and symposia were notified for the year 1948. Proposals were discussed for the publication of a catalogue of type-specimens of animal species and of historic collections, for the distribution of artificial radioactive isotopes for biological experiments and for the creation of a centre for marine biology in the Malay Archipelago. A resolution was adopted urging that all possible means be taken to prevent biological warfare. It was agreed to hold the next meeting in 1950, probably in Stockholm. The following officers were elected : President, Dr. M. J. Sirks (Netherlands); Vice-President, Prof. H. Munro Fox (Great Britain); General Secretary, Prof. P. Vayssière (France); Secretary, Prof. Stuart Mudd (United States); and Treasurer, Prof. Chodat (Switzerland).

\section{Chemistry and Uses of Fluorine}

A WHOLE number of Industrial and Engineering Chemistry (39, 236-435; March 1947) is devoted to the chemistry of fluorine and its compounds. The production of fluorine on the industrial scale and its storage and utilization are fully described. The common electrolytes are fused acid potassium fluorides with carbon anodes, and up to 2,000 amperes were used in the electrolysing currents. An anode current efficiency of about 95 per cent was attained. Small laboratory units are also dealt with. The gas can be piped in steel or copper, and compressed up to $400 \mathrm{lb}$. in. $^{2}$ in nickel and steel cylinders. Purification reached 98 per cent minimum. Fluorination of hydrocarbons formed numerous products up to $\mathrm{C}_{18} \mathrm{~F}_{30}$, and in this work much use was made of cobalt trifluoride, $\mathrm{CoF}_{3}$, and silver difluoride, $\mathrm{AgF}_{2}$, and reactions in liquid hydrogen fluoride. A novelty is the fluorine-hydrogen blowpipe, used for welding metals. The papers represent a notable advance in fluorine chemistry.

\section{Archæological Work in China}

Occasional Papers (vol. 1, No. 1) of the Freer Gallery of Art (Smithsonian Institution) is devoted to a description of the tomb of the Grand Empress Dowager Wên Ming and the Northern Wei necropolis at Fang Shan. The author (A. G. Wenley) has produced an interesting little work of some 28 pages with six full-page photographs of the site. It starts with a short account of the Empress Dowager herself, followed by a description of the necropolis and tomb where she is buried. The work itself is dedicated to the late Carl Whiting Bishop, who was associated with the Freer Gallery for twenty years and who was much interested in certain Northern Wei dynasty imperial mausolea.

\section{German Food Industry in War-time}

As exhibition of photographs, drawings and specimens obtained in Germany by British Intelligence Objectives Sub-Committee investigating teams sponsored by the Ministry of Food will be on view in the Conference Hall, Portman Court, Portman Square, W.1, during October 15-29 each day from 10 a.m. to 4 p.m. Informal talks will be given in the exhibition at 3 p.m. on German soapless detergents (Mr. G. R. Perdue, British Launderers' Research Association); developments in the German dairying industry (Mr. F. C. White, Ministry of Food) ; war-time production of food yeast in Germany (Mr. H. J. Bunker, Barclay Perkins and Co., Ltd.); food preservation and refrigeration in Germany (Dr. E. C. Bate-Smith, Department of Scientific and Industrial Research).

\section{University of London: Appointments}

THE following appointments in the University of London have been announced: Mr. M. McGregor Cooper, senior lecturer in dairy husbandry at Massey Agricultural College, New Zealand, to the University chair of agriculture tenable at Wye College; Prof. W.J. Hamilton, since 1945 regius professor of anatomy in the University of Glasgow, to the University chair of anatomy tenable at Charing Cross Hospital Medical School; Prof. W. G. Holford, since 1931 Lever professor of civic design in the University of Liverpool, to the University chair of town planning tenable at University College; Dr. W. A. Lewis, lecturer in commerce at the London School of Economics and also principal in the Board of Trade and in the Colonial Office, to the University readership in Colonial economics tenable at the School.

The title of reader in mining geology in the University has been conferred on Dr. David Williams, in respect of the post held by him at the Imperial College of Science and Technology.

\section{Announcements}

The sixth Hinchley Memorial Lecture of the Institution of Chemical Engineers will be delivered by Dr. R. V. Southwell, rector of the Imperial College of Science and Technology, on October 14 at 5.30 p.m. at the Institution of Mechanical Engineers, Storey's Gate, London, S.W.1. Dr. Southwell will speak on "Relaxation Methods : a Method for the Engineer',

Dr. E. Ashworth UNDERwood, director of the Wellcome Historical Medical Museum and honorary lecturer in the University of London (University College), has been awarded the Cross of the Chevalier of the Legion of Honour. 